Sains Malaysiana 50(5)(2021): 1485-1496

http://doi.org/10.17576/jsm-2021-5005-27

\title{
Malaysian Dentists' Self-Reported Experience towards Continuing Clinical Activity during the COVID-19 Pandemic
}

(Pegawai Pergigian di Malaysia Melaporkan Pengalaman Sendiri Meneruskan Aktiviti Klinikal semasa Pandemik COVID-19)

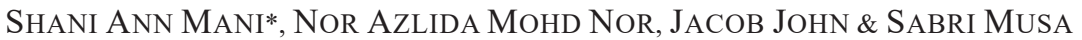

\begin{abstract}
This study assessed the self-reported symptoms/signs and precautionary measures towards continuing clinical practice during the second wave of the COVID-19 pandemic among Malaysian dentists. An online questionnaire was administered using Google Form distributed via social networks, email lists and social media pages to Malaysian dentists in both private and government sectors. Respondents were required to report their clinical activity during the three phases of the various Movement Control Order (MCO) imposed by the Malaysian government: namely the MCO, ConditionalMCO and the Recovery-MCO. Data was analysed with SPSS using descriptive and Chi-square tests. A total of 1548 dentists completed the survey. Five dentists reported being tested positive for COVID-19 test while 48 had one/more symptoms related to the disease. The majority perceived a real risk of COVID-19 transmission to dentists and more than $80 \%$ limited their clinical services to emergency/selective care during the MCO and C-MCO. About $17 \%$ of the dentists suspended face-to-face clinical activities during the MCO period but this figure dropped to 3.4\% during the R-MCO. Clinical activities were limited mainly due to closure of workplaces (88.6\%). Precautionary measures adopted at dental clinics included recording body temperature (54.2\%), physical distancing in waiting rooms (84.6\%) and hand washing prior to and after dental procedures (77.5\%). The findings demonstrate that most dentists limited their clinical services during the MCO and resumed work once restrictions were lifted during the C-MCO and R-MCO. Many reported adopting appropriate precautionary measures to mitigate the spread of COVID-19.
\end{abstract}

Keywords: Clinical practice; COVID-19; dentists; pandemic; $M C O$

ABSTRAK

Kajian ini bertujuan untuk menilai gejala/tanda COVID-19 dan langkah pencegahan terhadap kesinambungan amalan klinikal semasa gelombang kedua penularan wabak COVID-19 di kalangan pegawai pergigian di Malaysia. Soal selidik ini diberikan secara dalam talian menggunakan borang Google yang diedarkan melalui rangkaian sosial, e-mel dan media sosial kepada pegawai pergigian di Malaysia yang berkhidmat di sektor awam dan swasta. Responden diminta melaporkan aktiviti klinikal mereka selama tiga fasa Perintah Kawalan Pergerakan (PKP) yang dilaksanakan oleh kerajaan Malaysia, iaitu PKP, PKP-Bersyarat (PKPB) dan PKP-Pemulihan (PKPP). Data dianalisa dengan SPSS menggunakan ujian deskriptif dan khi kuasa dua. Seramai 1,548 pegawai pergigian menjawab kaji selidik ini. Seramai 5 orang pegawai pergigian dilaporkan sebagai positif COVID-19 dan 48 orang didapati mempunyai satu/lebih gejala yang berkaitan dengan COVID-19. Kebanyakan daripada mereka merasakan penularan COVID-19 berisiko kepada pegawai pergigian dan lebih daripada $80 \%$ telah mengehadkan perkhidmatan klinikal kepada rawatan kecemasan/selektif semasa PKP dan PKPB. Sekitar 17\% pegawai pergigian menangguhkan aktiviti klinikal secara bersemuka dalam tempoh PKP dan peratusan tersebut menurun kepada 3.4\% semasa PKPP. Faktor utama kegiatan klinikal yang terhad adalah kerana penutupan tempat kerja (88.6\%). Langkah pencegahan yang dilakukan di klinik pergigian termasuk mencatat suhu badan (54.2\%), penjarakan fizikal di ruang menunggu (84.6\%) dan mencuci tangan sebelum dan selepas prosedur pergigian (77.5\%). Hasil kajian menunjukkan bahawa kebanyakan pegawai pergigian mengehadkan perkhidmatan klinikal mereka semasa PKP dan menyambung semula aktiviti klinikal setelah kelonggaran diberikan semasa tempoh PKPB dan PKPP. Kebanyakan responden melaporkan mengamalkan langkah pencegahan untuk mengekang penularan COVID-19.

Kata kunci: Amalan klinikal; COVID-19; pandemik; pegawai pergigian; PKP 


\section{INTRODUCTION}

The global community was jolted by the rapidly spreading, deadly coronavirus disease 2019 (COVID-19) in early 2020 and continues to reel over the damage caused by the severe acute respiratory syndrome coronavirus 2 (SARSCoV-2) (Joint Statement by ILO, FAO, IFAD and WHO 2020). Declared a Public Health International Emergency in January 2020, and as pandemic by $11^{\text {th }}$ March 2020, the WHO published guidelines and recommendations on multiple actions such as extensive testing, contact tracing, quarantining and social distancing to curb its spread and the use of Personal Protection Equipment (PPE) by health care workers as the primary form of prevention (WHO 2020a). Nevertheless, the number of COVID-19 cases continued to rise with 2 million infected people reported weekly by the end of September 2020 and with more than 1 million deaths worldwide (WHO 2020b). The number of COVID-19 cases in Malaysia has been low compared to many other countries (Pfordten \& Ahmad 2020a). Overall, reported cases in Malaysia up to $15^{\text {th }}$ December, 2020 can be divided into three waves. The first wave was brought under control by $27^{\text {th }}$ February 2020, but was followed by a second wave and a third, more severe, wave which started on $20^{\text {th }}$ September 2020 that is still ongoing (Pfordten \& Ahmad 2020b). The Ministry of Health, Malaysia (MOHM) played a crucial role in ensuring maximum readiness to contain the spread of the virus (Shah et al. 2020). The Movement Control Order (MCO) was implemented on $18^{\text {th }}$ March 2020, followed by the Conditional Movement Control Order (C-MCO) from $4^{\text {th }}$ May 2020 and the Recovery Movement Control Order (R-MCO) from $10^{\text {th }}$ June 2020 till the end of 2020. With the third wave, zones were placed on a C-MCO contingent on the risk, with restrictions based on the requirement to curb the spread of the disease. The MOHM diligently conducted daily press briefings on COVID-19 to ensure public awareness of and access to accurate information (Shah et al. 2020).

Reports of COVID-19 spreading to the frontline workers surfaced early in the pandemic (Nguyen et al. 2020). The dental fraternity also faced the threats and uncertainties involved in the spread of COVID-19 during dental treatment (Fallahi et al. 2020). Although COVID-19 patients were not supposed to receive dental treatment, undiagnosed infected subjects without or with very mild symptoms continued to be eligible for dental treatment in emergency cases (Cagetti et al. 2020). Since dental treatment predominantly involves the generation of aerosols, suggestions for PPEs, types of treatment to be avoided and guidelines for treatment were put forward by transnational organizations (Jamal et al. 2020). The MOHM published guidelines in English and the local language, Bahasa Melayu (BM) for dental health care workers on their website on 17 April 2020, to control the spread of COVID-19 during dental services delivery in Malaysia (Oral Health Program 2020).

Amid a rapidly spreading pandemic caused by a deadly respiratory virus, dentists worldwide neither had prior experience nor were equipped to follow the constantly evolving guidelines for dental practice. In this situation, as part of the global survey conducted by the WHO collaboration Centre for Epidemiology and Community Dentistry at the University of Milan, in Italy, this survey was undertaken in Malaysia to assess dentists' self-reported symptoms/signs, precautionary measures towards continuing clinical practice during the second wave of the COVID-19 pandemic in Malaysia.

\section{MATERIALS AND METHODS}

\section{STUDY DESIGN AND DATA COLLECTION}

Ethical approval to conduct this study was obtained from the Medical Ethics Committee, Faculty of Dentistry, University of Malaya (DFCD2012/0061(L) and Medical Research and Ethics committee, MOHM (NMRR-20-110655235).

This was a web-based questionnaire survey conducted among registered dentists in Malaysia. A validated questionnaire was adopted from WHO global survey on symptoms/signs, protective measures, level of awareness and perception on the COVID-19 outbreak among dental health care workers (Campus et al. 2020). The questionnaire included in the present analysis comprised of 17 questions based on a closed-ended and a Likertscale answer format. Five questions covered demographic characteristics, 3 were on self-reported COVID-19 tests and symptoms, 5 on clinical activity during the pandemic, 1 each on precautionary measures taken by dentists in the clinic and reasons for limiting or stopping clinical activity, and 2 addressed the knowledge and self-perceived risks of COVID-19 infection. In relation to questions on clinical activity, respondents were required to report their clinical activity during the three phases of the pandemic control measures imposed by the Malaysian government, namely the MCO (18 March to 4 May 2020), C-MCO (4 May to 9 June 2020), and R-MCO (10 June to 31 December 2020). 
The questionnaire was translated to BM using a forward and backward translation process by authors and two linguistic experts, followed by a face validation process by three dental experts from the Ministry of Health and the University of Malaya.

Minor changes were made following expert feedback in relation to the language in the questionnaire. A pilot study was then conducted among 14 dentists to check semantic comprehension of both versions of the questionnaires. To determine its reliability, the questionnaire was re-sent to the sample involved in the pilot study 5 days after its first administration. Only minor modifications were made to the questionnaire following feedback from the pilot study. The final bilingual questionnaire was administered using Google Forms from 1 to 15 July 2020, distributed via email to: Principal Director, Oral Health Programme, Ministry of Health, Malaysia; President, Malaysian Dental Association; Deans of Academic Institutions, and Dental Director Malaysian Armed Forces, Health Services Division, Ministry of Defence, Malaysia. Additionally, the link was circulated via WhatsApp and the Facebook pages of relevant dental associations/institutions in Malaysia. This survey was anonymous and did not contain personal sensitive data.

Sample size calculation was based on a single proportion formula (Arifin 2013; Naing et al. 2006) using epitools.ausvet.com.au. This calculator used the following formula for the sample size; $n=\left(Z^{2} \times P\right.$ $(1 / P)) / e^{2}$. Where $Z$ is the value from standard normal distribution corresponding to desired confidence level ( $\mathrm{Z}=1.96$ for $95 \% \mathrm{CI}$ ); $\mathrm{P}$ is the expected true proportion; $\mathrm{e}$ is the desired precision (half desired CI width). The calculation was based on the number of registered dentists having annual practising certificates in 2019 by the Malaysian Dental Council ( $\mathrm{n}=10,801)$, with an estimated proportion of $50 \%$, precision at $5 \%$ and confidence level of $95 \%$. The minimum sample size required was 385 . All registered dentists that received the online survey link were invited to participate in this study. Representatives from various dental organizations were requested to share the questionnaire link with fellow colleagues along with regular follow-up and reminders, in an attempt to ensure the questionnaire reached maximum number of dentists nationwide to improve the response rate.

\section{DATA ANALYSIS}

The response rate was calculated based on spontaneous response from participants within the study period. Data from Google Form were transferred to SPSS version 24.2 (IBM). During data analysis, age was categorised into 3 groups $(<35,35-45,>45$ years $)$. For employment status, data were grouped into 4 broad categories as public, private (general practitioners), academicians (public and private dental institutions), and both (public and private) sectors. Public sector included those working in the Ministry of Health and Armed Forces. Academicians in public and private dental institutions were grouped together, reflecting the similar nature of work in academia. They were also grouped based on nature of work as specialist or general dental practitioner. A four-point Likert scale question (1-very likely, 2-likely, 3-unlikely and 4-very unlikely) was re-coded into two groups (likely and unlikely). In terms of clinical activity, clinicians were categorised into three; those who continued clinical work as usual; those who limited face to face activity to selective/ emergency work and those who reportedly stopped all face-to-face clinical activities and only provided remote clinical advice/consultation. Data were analysed using descriptive statistics and Chi-square tests. The significant value was set at $\mathrm{p}<0.05$.

\section{RESULTS}

Altogether 1,548 Malaysian dentists responded to the online questionnaire. Table 1 shows the demographic characteristics of the study participants. A total of 105 (7\%) respondents involved in administrative work were not included in the analysis, thus, giving a sample of 1,443 involved in clinical work. Those involved in clinical work were mostly from the public sector $(79.8 \%$ ) while $8.8 \%$ were in the private sector. Only a small proportion (4.6\%) reported working in both sectors. The majority of the respondents were general dental practitioners $(86.7 \%)$ and female (89.9\%) with ages ranging from 23 to 65 years, with a mean age of 34.57 years. A higher proportion of young dentists (aged below 35), at $61.5 \%$, completed the questionnaire compared to those in the older age groups. The majority reported not being in the high-risk group for COVID-19 due to comorbidities (83.2\%). About 10.3\% of them declared having undergone COVID-19 testing between 18 March and 15 July 2020, with $0.3 \%$ reporting positive for the test. Forty eight dentists reported having COVID-19 related symptoms/signs, the most common symptoms being coughs and sore throat (Table 2). 
TABLE 1. Demographic characteristics of study participants

\begin{tabular}{|c|c|c|}
\hline Variable & $\mathrm{n}$ & $(\%)$ \\
\hline \multicolumn{3}{|l|}{ Gender $(\mathrm{n}=1548)$} \\
\hline Male & 157 & $(10.1)$ \\
\hline Female & 1391 & $(89.9)$ \\
\hline \multicolumn{3}{|l|}{ Age (years) $(n=1548)$} \\
\hline$<35$ & 952 & $(61.5)$ \\
\hline $35-45$ & 403 & $(26)$ \\
\hline$>45$ & 193 & $(12.5)$ \\
\hline \multicolumn{3}{|c|}{ Belonging to the high-risk group for COVID-19 due to comorbidities ( $\mathrm{n}=1548)$} \\
\hline Yes & 260 & $(16.8)$ \\
\hline No & 1288 & $(83.2)$ \\
\hline \multicolumn{3}{|l|}{ Employment $*(n=1443)$} \\
\hline Public sector (Ministry of Health, Malaysian Armed Forces) & 1140 & $(73.6)$ \\
\hline Public and Private dental schools (Academicians) & 105 & $(6.8)$ \\
\hline Private (general practitioners) & 127 & $(8.2)$ \\
\hline Both public and private & 71 & $(4.6)$ \\
\hline \multicolumn{3}{|l|}{ Working status $*(n=1443)$} \\
\hline Specialist & 192 & $(12.4)$ \\
\hline General Practitioner & 1251 & $(80.8)$ \\
\hline \multicolumn{3}{|l|}{ Underwent COVID-19 test $(\mathrm{n}=1548)$} \\
\hline Yes & 160 & $(10.3)$ \\
\hline No & 1388 & $(89.7)$ \\
\hline \multicolumn{3}{|l|}{ COVID-19 test and related symptoms $(n=1548)$} \\
\hline Tested positive for COVID-19 & 5 & $(0.3)$ \\
\hline Had one/more COVID-19 symptoms & 48 & (2.9) \\
\hline Hospitalised for COVID-19 & 1 & $(0.1)$ \\
\hline
\end{tabular}

* Less than $100 \%$ due to exclusion of dentists $(\mathrm{n}=105,6.8 \%)$ who reportedly were only involved in administrative duties and not clinical work 
TABLE 2. Prevalence of associated symptoms/signs related to COVID-19 among dentists

\begin{tabular}{lrl}
\hline Symptoms & $\mathrm{n}$ & $\%$ \\
\hline Fever $\left(>37.5^{\circ} \mathrm{C}\right)$ & 18 & $(1.2)$ \\
Cough & 30 & $(2.1)$ \\
Fatigue & 7 & $(0.5)$ \\
Difficulty breathing & 14 & $(1.0)$ \\
Nasal congestion & 18 & $(1.2)$ \\
Headache & 9 & $(0.6)$ \\
Nose bleed & 1 & $(0.1)$ \\
Sore throat & 31 & $(2.1)$ \\
Generalised body pain & 5 & $(0.3)$ \\
Diarrhea & 4 & $(0.3)$ \\
Loss of smell & 5 & $(0.3)$ \\
Loss of taste & 5 & $(0.3)$ \\
Conjunctivitis & 2 & $(0.1)$ \\
\hline
\end{tabular}

Participants also responded regarding their continuance of clinical activity immediately prior to the MCO and during its three stages. The majority (90\%) maintained their face-to-face clinical practices as usual before MCO implementation while more than $80 \%$ restricted themselves to emergency/selective care during the MCO and C-MCO. About $17 \%$ of the respondents completely ceased face-to-face clinical activities during the MCO period though this figure declined to $3.4 \%$ during the R-MCO. Data categorised in terms of continuing, limiting or suspending clinical activities during the different stages of MCOs is depicted in Figure 1. Although there was a drastic drop in the number of dentists who continued their routine clinical work when the MCO was declared the proportions steadily increased over the MCO to R-MCO periods.

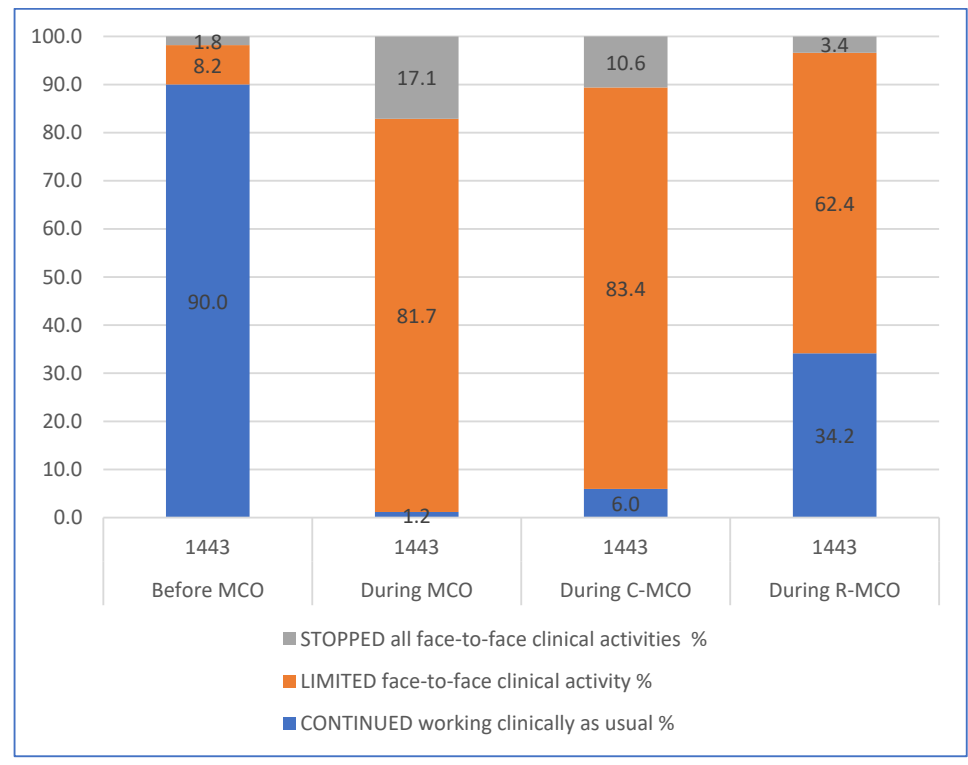

FIGURE 1. Continuity of clinical work among Malaysian dentists in three stages of movement control order (MCO) during second wave of COVID-19 pandemic 
Table 3 shows the precautionary measures taken by dentists who limited and continued to work during the second wave of the COVID-19 pandemic. Out of a total of 1443 dentists, 290 respondents indicated that they did not treat patients from $18^{\text {th }}$ March 2020 till the time of the survey. The most commonly adopted measures before patient arrival were checking body temperature (54.2\%) and reducing the number of appointments to minimise congestion in waiting rooms (61\%). Among measures taken in the waiting and operating rooms included 1-meter physical distancing between patients $(84.6 \%)$, sanitizing patients' hands $(71.9 \%)$, and hand-washing before and after procedures $(77.5 \%)$. The most common pre-operative mouth-rinse used was $1 \%$ hydrogen peroxide $(44.5 \%)$, followed by chlorhexidine (21\%). About one third (40.5\%) used $70 \%$ ethyl alcohol for disinfecting surfaces.

TABLE 3. Precautionary measures taken by dentists who continued clinical work during the second wave of COVID-19 in Malaysia $(\mathrm{N}=1153)$

\begin{tabular}{|c|c|c|}
\hline Item & $\mathrm{n}$ & $(\%)$ \\
\hline \multicolumn{3}{|l|}{ Before patient arrival } \\
\hline Telephone Triage & 269 & $(23.3)$ \\
\hline Appointments reduced so as not to fill the waiting room & 703 & $(61.0)$ \\
\hline Postponement of appointments for elderly or vulnerable patients & 431 & $(37.4)$ \\
\hline Check body temperature of all co-workers \& sent home those with above $37.5^{\circ} \mathrm{C}$ & 786 & $(68.2)$ \\
\hline \multicolumn{3}{|l|}{ In the waiting room } \\
\hline Disinfection of push buttons, chairs, several times a day & 704 & $(61.1)$ \\
\hline Verify patient's current health status on/before arrival & 649 & $(56.3)$ \\
\hline Check patient's body temperature & 625 & $(54.2)$ \\
\hline Sanitizing patients' hands & 829 & $(71.9)$ \\
\hline Maintain at least 1-metre space between patients in the waiting room & 976 & $(84.6)$ \\
\hline Patients wait in their car until called into the clinic for their appointment & 187 & $(16.2)$ \\
\hline Masks for patients whilst in the waiting room & 684 & $(59.3)$ \\
\hline Frequent ventilation of waiting rooms & 352 & $(30.5)$ \\
\hline Removal of magazines and books from the waiting area & 241 & $(20.9)$ \\
\hline Storage of bags and other items outside the operating area & 276 & $(23.9)$ \\
\hline \multicolumn{3}{|l|}{ In the operating room } \\
\hline Pre-operative rinse with mouthwash containing $1 \%$ hydrogen peroxide & 513 & $(44.5)$ \\
\hline Pre-operative rinse with mouthwash containing chlorhexidine $0.12-0.2 \%$ & 242 & $(21.0)$ \\
\hline Pre-operative rinse with mouthwash containing $0.2-1 \%$ iodopovidone & 100 & $(8.7)$ \\
\hline Pre-operative rinse with mouthwash containing alcohol and essential oils & 15 & $(1.3)$ \\
\hline Pre-operative rinse with mouthwash containing $0.05-0.10 \%$ Cetylpyridinium chloride & 11 & $(0.9)$ \\
\hline Rinse with diluted mouthwash & 68 & $(5.9)$ \\
\hline Ventilation of the operating area for at least $10 \mathrm{~min}$ after each patient & 324 & $(28.1)$ \\
\hline Stop all procedures for at least $10 \mathrm{~min}$ after each patient & 213 & $(18.5)$ \\
\hline Surface disinfection with $70 \%$ ethyl alcohol & 467 & $(40.5)$ \\
\hline Surface disinfection with $0.5 \%$ sodium hypochlorite & 224 & $(19.4)$ \\
\hline Surface disinfectant with other active ingredients & 310 & $(26.9)$ \\
\hline Washing operators' hands before and after each procedure & 894 & $(77.5)$ \\
\hline Disposal of all disposable protective devices and disinfection of non-disposable devices & 745 & $(64.6)$ \\
\hline
\end{tabular}


Reasons reported for limiting or stopping clinical activity during the COVID-19 pandemic are presented in Table 4. Although most reported the main reasons as closure of the workplace $(88.6 \%)$, only $54.6 \%$ agreed that it was due to implementation of the MCO. More than half reported they felt unsafe and did not have sufficient protection measures.

TABLE 4. Reasons for dentists' limiting or stopping clinical activity during the second wave of the COVID-19 pandemic in Malaysia $(\mathrm{N}=1443)$

\begin{tabular}{lrl}
\hline Reasons for limiting or stopping clinical activity & $\mathrm{n}$ & $(\%)^{*}$ \\
\hline My workplace was closed & 1372 & $(88.6)$ \\
I felt unsafe regarding possible infection & 790 & $(51.0)$ \\
I did not have sufficient protection measures & 792 & $(51.2)$ \\
Due to the implementation of MCO & 845 & $(54.6)$ \\
I thought it was my duty to close my practice & 69 & $(4.5)$ \\
I feared sharp decrease in demand due to MCO & 24 & $(1.6)$ \\
\hline
\end{tabular}

*Total not equal to $100 \%$, since multiple responses were permitted

Among those who reported continuing their clinical practice was further analysed to explore any association with demographic characteristics (Table 5). The results show that more female dentists tended to continue clinical work during the pandemic than their male counterparts with significant differences during the C-MCO period. The results show no marked difference in terms of age group. Significantly, a higher number of dentists with comorbidities limited or suspended their clinical activities though the numbers declined during the MCO, C-MCO and R-MCO periods.
The majority of them perceived having adequate knowledge of COVID-19 and there was no significant relationship to the proportion who continued clinical activity over the MCO to R-MCO periods (Table 6). Similarly, most felt there was a real risk of transmission of COVID-19 to dentists. A higher proportion were more conscious of the risks of COVID-19 during the C-MCO and R-MCO despite the majority $(96.5 \%)$ resuming clinical work during R-MCO. In contrast, a small proportion $(3.5 \%)$ felt that the risk of transmission of COVID-19 to dentists was unlikely during R-MCO. 
TABLE 5. Association between demographic characteristics and continuation of clinical activity in the three MCO stages during the second wave of the COVID-19 pandemic in Malaysia

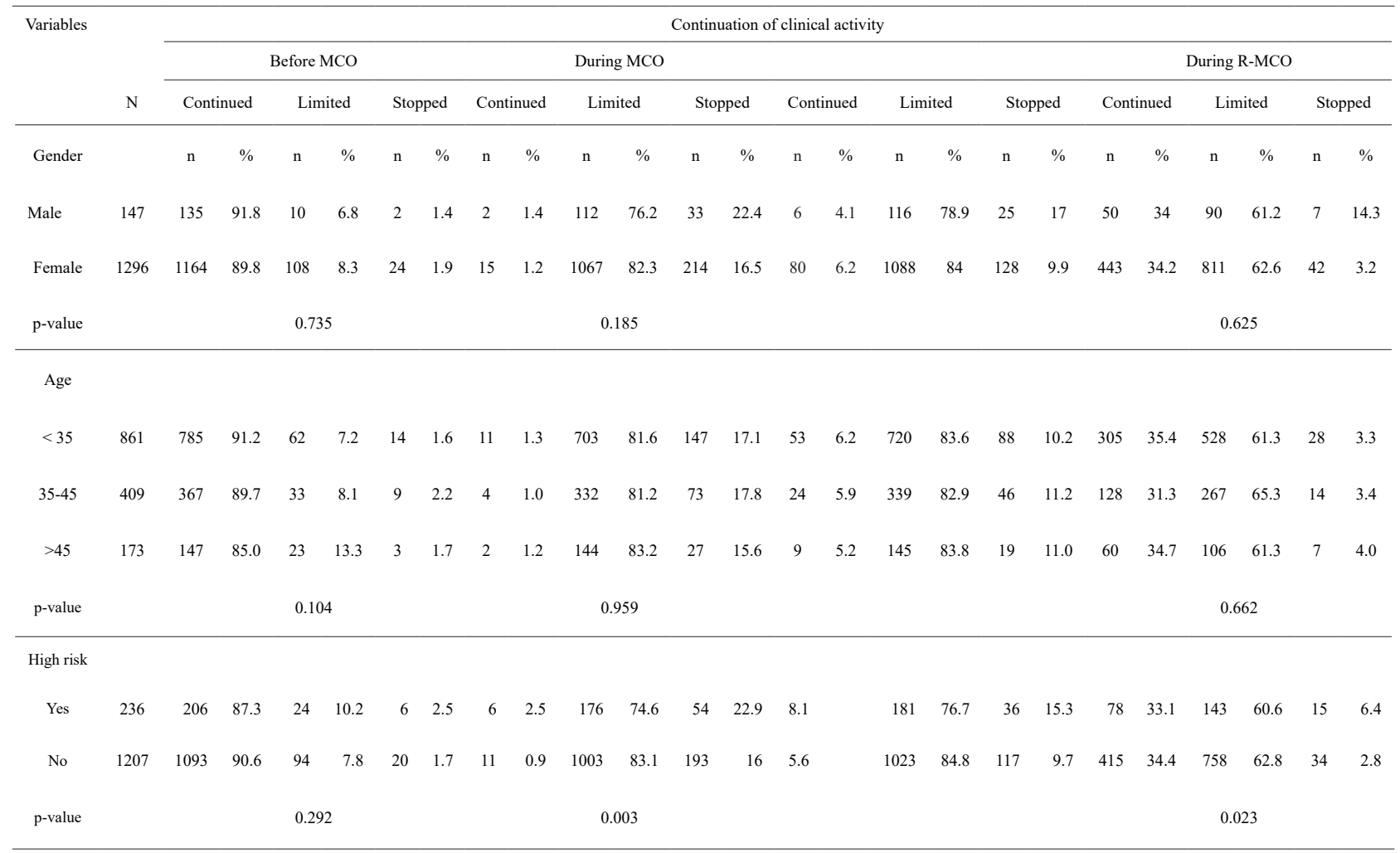

TABLE 6. Dentists perceived knowledge and risks for COVID-19 transmission and its association with their clinical activity during the three MCO stages during second wave of the COVID-19 pandemic in Malaysia

\begin{tabular}{|c|c|c|c|c|c|c|c|c|c|c|c|c|c|c|c|c|c|c|c|c|c|c|c|c|c|}
\hline \multirow{4}{*}{$\begin{array}{l}\text { Variables } \\
\\
\begin{array}{l}\text { Perceived } \\
\text { Knowledge }\end{array}\end{array}$} & \multirow{4}{*}{$\mathrm{N}$} & \multicolumn{24}{|c|}{ Continuation of clinical activity } \\
\hline & & \multicolumn{6}{|c|}{ Before MCO } & \multicolumn{6}{|c|}{ During $\mathrm{MCO}$} & \multicolumn{6}{|c|}{ During C-MCO } & \multicolumn{6}{|c|}{ During R-MCO } \\
\hline & & \multicolumn{2}{|c|}{ Continued } & \multicolumn{2}{|c|}{ Limited } & \multicolumn{2}{|c|}{ Stopped } & \multicolumn{2}{|c|}{ Continued } & \multicolumn{2}{|c|}{ Limited } & \multicolumn{2}{|c|}{ Stopped } & \multicolumn{2}{|c|}{ Continued } & \multicolumn{2}{|c|}{ Limited } & \multicolumn{2}{|c|}{ Stopped } & \multicolumn{2}{|c|}{ Continued } & \multicolumn{2}{|c|}{ Limited } & \multicolumn{2}{|c|}{ Stopped } \\
\hline & & $\mathrm{n}$ & $\%$ & $\mathrm{n}$ & $\%$ & $\mathrm{n}$ & $\%$ & $\mathrm{n}$ & $\%$ & $\mathrm{n}$ & $\%$ & $\mathrm{n}$ & $\%$ & $\mathrm{n}$ & $\%$ & $\mathrm{n}$ & $\%$ & $\mathrm{n}$ & $\%$ & $\mathrm{n}$ & $\%$ & $\mathrm{n}$ & $\%$ & $\mathrm{n}$ & $\%$ \\
\hline Yes & 960 & 856 & 89.2 & 86 & 9.0 & 18 & 1.9 & 10 & 1.0 & 782 & 81.5 & 168 & 17.5 & 58 & 6.0 & 796 & 82.9 & 106 & 11.0 & 336 & 35.0 & 594 & 61.9 & 30 & 3.1 \\
\hline No & 483 & 443 & 91.7 & 32 & 6.6 & 8 & 1.7 & 7 & 1.4 & 397 & 82.2 & 79 & 16.4 & 28 & 5.8 & 408 & 84.5 & 47 & 9.7 & 157 & 32.5 & 307 & 63.6 & 19 & 3.9 \\
\hline p-value & & \multicolumn{6}{|c|}{0.293} & \multicolumn{6}{|c|}{0.698} & \multicolumn{6}{|c|}{0.724} & \multicolumn{6}{|c|}{0.509} \\
\hline \multicolumn{26}{|l|}{$\begin{array}{l}\text { Perceived } \\
\text { Risk }\end{array}$} \\
\hline Likely & 1392 & 1252 & 89.9 & 116 & 8.3 & 24 & 1.7 & 16 & 1.1 & 1139 & 81.8 & 237 & 17 & 75 & 5.4 & 1168 & 83.9 & 149 & 10.7 & 467 & 33.5 & 876 & 62.9 & 49 & 3.5 \\
\hline Unlikely & 51 & 47 & 92.2 & 2 & 3.9 & 2 & 3.9 & 1 & 2.0 & 40 & 78.4 & 10 & 19.6 & 11 & 21.6 & 36 & 70.6 & 4 & 7.8 & 26 & 51.0 & 25 & 49.0 & 0 & 0.0 \\
\hline p-value & & \multicolumn{6}{|c|}{0.284} & \multicolumn{6}{|c|}{0.765} & \multicolumn{6}{|c|}{0.000} & \multicolumn{6}{|c|}{0.021} \\
\hline
\end{tabular}




\section{DISCUSSION}

Early in the COVID-19 pandemic, dentistry was listed as one of the occupations in a non-hospital setting with the greatest risk of contracting the SARS-CoV-2 ( $\mathrm{Lu}$ 2020). Simultaneously, multinational guidelines for dental treatment were released the world over including Malaysia (Jamal et al. 2020; Oral Health Progam 2020). Dentists routinely have close face-to-face contact with patients and are likely to be exposed either by: direct exposure to respiratory secretions containing droplets, indirect contact with contaminated surfaces, inhaling suspended airborne virus or mucosal contact with infected droplets or aerosols (Fallahi et al. 2020; WHO 2020c). Many dental procedures generate droplets or aerosols, hence patients with COVID-19 infections should not be routinely treated in a dental care setting (WHO 2020c). This study attempted to understand dentists' self-reported experience towards dental practice during the second wave of the COVID-19 pandemic in Malaysia.

Majority of the respondents were from the government sector $(79 \%)$, reflecting the distribution of dentists employed in Malaysia, where the government sector has almost double that of the private sector (Malaysian Dental Council 2019). In addition, 89\% of the respondents were females, reflecting the femaledominant dental workforce in Malaysia with a M:F ratio of 1:2.26 (Malaysian Dental Council 2019). Similar female majorities were noted in surveys of dentists in Poland and Jordan (Khader et al. 2020; Tysiac-Mista \& Dziedzic 2020). Understandably, most of the respondents were from the younger age group ( $<35$ years $)$, since they are more likely to access online questionnaires distributed via social networks (Malaysian Communications and Multimedia Commission 2020). There were less than 10,000 COVID-19 infections in Malaysia at the completion of this study (WHO $2020 \mathrm{~d})$ and this is reflected in the low number of dentists $(0.3 \%)$ who tested positive. However, it is not clear if the transmission of COVID-19 infection to these individuals were from a clinical setting or from routine social contact.

One of the risk factors accounting for the severity of COVID-19 is the presence of co-morbidities (Pantea Stoian et al. 2020). In our study sample, $16.8 \%$ believed they were at high risk for COVID-19 infection based on their age and/ or health status and this was significantly associated with those who limited or suspended clinical work during the $\mathrm{MCO}, \mathrm{C}-\mathrm{MCO}$, and R-MCO. Additionally, significantly more males limited or suspended clinical work during C-MCO, possibly because being male places individuals at a higher risk for severe disease (Pantea Stoian et al. 2020). This is in contrast to Poland, where more females suspended clinical activity (Tysiac-Mista \& Dziedzic 2020). Our study findings suggest that dentists were aware of their high-risk status, having taken necessary precautions during the various phases of MCO. On the other hand, significant differences were not seen prior to the government-declared $\mathrm{MCO}$, indicating that these high-risk dentists had not perceived the need to alter their work patterns despite few COVID-19 cases being reported in Malaysia prior to the MCO (Elengoe 2020). This is possibly because many countries including Malaysia downplayed the severity of the illness and assumed that it would not be widespread (Aziz et al. 2020).

Daily media press conferences in Malaysia created a sense of security and confidence among the public (Aziz et al. 2020) and may have mitigated the spread of the disease during the initial stage of the outbreak (Zhou et al. 2020). Despite concerted efforts by the Malaysian government to disseminate information related to SARS-CoV-2 transmission and its prevention (Aziz et al. 2020; Elengoe 2020), slightly above $30 \%$ of dentists in this survey perceived they had insufficient knowledge regarding COVID-19. The perceived lack of knowledge is possibly due to the uncertain nature of the pandemic as well as the multiple sources of information on it (Duruk et al. 2020) and misinformation spread on social media (Apuke \& Omar 2020). Perhaps, increased awareness can be achieved by local dental authorities communicating updated guidelines personally to all registered dentists during a crisis through affordable measures such as emails (Khader et al. 2020) or on mobile phones apps (Kinariwala et al. 2020). In other countries, specific issues addressing aspects of COVID-19 showed that dentists had adequate knowledge on the disease (Chowdhury et al. 2020; Khader et al. 2020).

Regardless of their perceived level of knowledge, the number of dentists who continued with clinical practice increased in number, though not significantly, when the country went from MCO to C-MCO and on to R-MCO. This was more likely due to the low number of COVID-19 infections in Malaysia and a relaxation of lockdown rules, since $89 \%$ and $54 \%$ of dentists limited or stopped clinical activity due to workplace closures or MCO implementation, respectively. Moreover, only 51\% of dentists in Malaysia claimed they limited clinical activity on safety grounds due to the possibility of an infection or the lack of sufficient protective measures. Furthermore, other factors such as fear of losing jobs among the younger age groups and inability to sustain themselves economically for prolonged periods may have contributed to the decision to resume clinical activity (Aziz et al. 2020). Our study's findings are in contradiction with those of Poland and another multinational study where $71.2 \%$ 
and $65 \%$ suspended their clinical activity, respectively (Ahmed et al. 2020; Tysiac-Mista \& Dziedzic 2020). This could possibly be due to the higher number of infections in those countries.

In Italy, $85 \%$ of the dentists were concerned about contracting COVID-19 during clinical activity (Consolo et al. 2020). Similarly, $87 \%$ of dentists from 30 countries were afraid of contracting COVID-19 despite having a high standard of knowledge and practice, leading to many practices closing or modifying their services to satisfy the recommended guidelines (Ahmed et al. 2020). In contrast, dentists in Jordan perceived only moderate risks with one-third believing it to be not serious (Khader et al. 2020), and this may be associated with the lower number of cases. The number of dentists perceiving an increased risk of contracting COVID-19 from clinical practice was similar in Italy (93.41\%) (Cagetti et al. 2020) and Malaysia (95\%). Although $95 \%$ of dentists in Malaysia perceived a real risk of contracting COVID-19 during the second wave, $33.5 \%$ resumed normal clinical activity during the R-MCO despite having limited clinical practice when the preceding MCO and C-MCO were on. Probable reasons include perceived job insecurity, altruism, the responsibility expected from society (Koh et al. 2020) and the low number of infections in Malaysia. Most respondents, being from the government sector, had possibly resumed clinical work as part of their job commitments, suggesting that work status was determined by the government rules enforced at that period of time.

Many dentists who continued to practice incorporated changes in their dental practice as recommended by guidelines in this study. Prior to patient arrival, most of them reduced appointments as per recommendations, similar to other countries (Chowdhury et al. 2020) while in other countries fewer patients sought dental treatment (Tysiac-Mista \& Dziedzic 2020). In this study, precautions at the waiting area included sanitising patients' hands and maintaining a 1-meter distance between them. Meanwhile in the operating room, there were differences in the types of pre-procedural mouthwash used, due perhaps to the influence of different recommendations and depending on availability, as was found in another study (Duruk et al. 2020). Another study noted that dentists ignored the recommendation of using pre-procedural mouthwash (Ahmed et al. 2020). Similar actions, where dentists were quick to make the necessary changes to their practice were seen in other countries (Cagetti et al. 2020; Duruk et al. 2020; Tysiac-Mista \& Dziedzic 2020).

Literature published later in the pandemic shows that COVID-19 prevalence and testing positivity rates were low among practicing US dentists (Froum \& Froum 2020). The use of screening questionnaires, performing enhanced infection control, and having appropriate personal protective equipment can help curtail the transmission of COVID-19 to dental healthcare workers (Ren et al. 2020). This is likely to significantly increase the cost of dental health care, the brunt of which will be borne by patients (Tysiac-Mista \& Dziedzic 2020). Nevertheless, both patients and practitioners will be reassured knowing that such measures will significantly reduce the risk of COVID-19 transmission during dental treatment.

This survey is not without limitations. One of the limitations was that the sample had proportionally fewer private practitioners and academicians from the private dental institutions. Reasons may have been varied; however, we can speculate that since the pandemic caught most dentists off-guard and in a new uncertain situation causing undue anxiety, responding to a questionnaire may have been their last priority. Secondly, it can be argued that the questionnaire may not have reached all dentists in Malaysia using the online survey method, even though several strategies were in place. However, this method of data collection has been used globally in many populationbased studies as it is practical and cost-effective (Ebert et al. 2018). Secondly, items regarding knowledge and selfperceived risk were limited and may not have captured detailed aspects. This was to adhere to the original WHO global survey protocol (Campus et al. 2020) and to avoid increasing the length of the questionnaire further.

Few benefits also arose from this pandemic during which there was an extensive shutdown of dental services. Firstly, dentists are now better prepared for any future pandemic/epidemics involving fatal respiratory illnesses, like those surfacing in the past few decades such as SARS, MERS and currently SARS-CoV2. Secondly, we can anticipate improved infection control measures implemented in the dental clinics on a routine basis.

\section{CONCLUSION}

The uncertainty of the COVID-19 pandemic caught dentists in an unprepared situation. Non-urgent dental patient care was greatly affected during the MCO declared in Malaysia. Majority of dentists limited clinical work with some entirely suspending clinical activity altogether while those who continued providing care, implemented strict precautionary measures as per the recommendations. 


\section{ACKNOWLEDGMENTS}

The authors would like to thank the Director General of Health, Malaysia for permission to publish this paper.

\section{REFERENCES}

Ahmed, M.A., Jouhar, R., Ahmed, N., Adnan, S., Aftab, M., Zafar, M.S. \& Khurshid, Z. 2020. Fear and practice modifications among dentists to combat novel coronavirus disease (COVID-19) outbreak. Int. J. Environ. Res. Public Health 17(8): 2821.

Apuke, O.D. \& Omar, B. 2020. Modelling the antecedent factors that affect online fake news sharing on COVID-19: The moderating role of fake news knowledge. Health Educ. Res. 35(5): 490-503.

Arifin, W.N. 2013. Introduction to sample size calculation. Education in Medicine Journal 5(2): e89-e96.

Aziz, N.A., Othman, J., Lugova, H. \& Suleiman, A. 2020. Malaysia's approach in handling COVID-19 onslaught: Report on the Movement Control Order (MCO) and targeted screening to reduce community infection rate and impact on public health and economy. J. Infect. Public Health 13(12): 1823-1829.

Cagetti, M.G., Cairoli, J.L., Senna, A. \& Campus, G. 2020. COVID-19 outbreak in North Italy: An overview on dentistry. A questionnaire survey. Int. J. Environ. Res. Public Health 17(11): 3835.

Campus, G., Diaz-Betancourt, M., Cagetti, M.G., Carvalho, J.C., Carvalho, T.S., Cortés-Martinicorena, J.F., Deschner, J., Douglas, G.V.A., Giacaman, R., Machiulskiene, V., Manton, D.J., Raggio, D.P., Ramos-Gomez, F., Sava-Rosianu, R., Morozova, N.S., Spagnuolo, G., Vukovic, A., Wolf, T.G. $\&$ On Behalf of the, C.C.G. 2020. Study protocol for an online questionnaire survey on symptoms/signs, protective measures, level of awareness and perception regarding COVID-19 outbreak among dentists. A global survey. Int. J. Environ. Res. Public Health 17(15): 5598.

Chowdhury, M.T.H., Apu, E.H., Nath, S.K., Noor, A.E., Podder, C.P., Mahmud, I. \& Kabir, R. 2020. Exploring the knowledge, awareness and practices of COVID-19 among dentists in Bangladesh: A cross-sectional investigation. https://www.researchsquare.com/article/rs-56753/v1.

Consolo, U., Bellini, P., Bencivenni, D., Iani, C. \& Checchi, V. 2020. Epidemiological aspects and psychological reactions to COVID-19 of dental practitioners in the Northern Italy districts of Modena and Reggio Emilia. Int. J. Environ. Res. Public Health 17(10): 3459.

Duruk, G., Gumusboga, Z.S. \& Colak, C. 2020. Investigation of Turkish dentists' clinical attitudes and behaviors towards the COVID-19 pandemic: A survey study. Braz. Oral Res. 34: $\mathrm{e} 054$.

Ebert, J.F., Huibers, L., Christensen, B. \& Christensen, M.B. 2018. Paper- or web-based questionnaire invitations as a method for data collection: Cross-sectional comparative study of differences in response rate, completeness of data, and financial cost. J. Med. Internet Res. 20(1): e24.
Elengoe, A. 2020. COVID-19 outbreak in Malaysia. Osong Public Health Res. Perspect 11(3): 93-100.

Fallahi, H.R., Keyhan, S.O., Zandian, D., Kim, S.G. \& Cheshmi, B. 2020. Being a front-line dentist during the Covid-19 pandemic: A literature review. Maxillofac. Plast. Reconstr. Surg. 42(1): 12.

Froum, S.H. \& Froum, S.J. 2020. Incidence of COVID-19 virus transmission in three dental offices: A 6-month retrospective study. Int. J. Periodontics Restorative Dent. 40(6): 853-859.

Jamal, M., Shah, M., Almarzooqi, S.H., Aber, H., Khawaja, S., El Abed, R., Alkhatib, Z. \& Samaranayake, L.P. 2020. Overview of transnational recommendations for COVID-19 transmission control in dental care settings. Oral Dis. 27(S3): 655-664.

Joint Statement by ILO, FAO, IFAD and WHO. 2020. Impact of COVID-19 on people's livelihoods, their health and our food systems. https://www.who.int/news/item/13-10-2020impact-of-covid-19-on-people's-livelihoods-their-healthand-our-food-systems.

Khader, Y., Al Nsour, M., Al-Batayneh, O.B., Saadeh, R., Bashier, H., Alfaqih, M., Al-Azzam, S. \& AlShurman, B.A. 2020. Dentists' awareness, perception, and attitude regarding COVID-19 and infection control: Cross-sectional study among Jordanian dentists. JMIR Public Health Surveill 6(2): e18798.

Kinariwala, N., Samaranayake, L.P., Perera, I. \& Patel, Z. 2020. Concerns and fears of Indian dentists on professional practice during the coronavirus disease 2019 (COVID-19) pandemic. Oral Dis. 27(S3): 730-732.

Koh, B.Y.E., Pang, T.P.N., Shoesmith, W.D., James, S., Nor Hadi, N.M. \& Loo, J.L. 2020. The behaviour changes in response to COVID-19 pandemic within Malaysia. Malays J. Med. Sci. 27(2): 45-50.

Lu, M. 2020. The front line: Visualizing the occupation with the highest COVID-19 risk. https://www.visualcapitalist. com/the-front-line-visualizing-the-occupations-with-thehighest-covid-19-risk/. Accessed on 18th January 2021.

Malaysian Communications and Multimedia Commission (Producer). (2020). Internet Users survey 2020: Infographic. https://www.mcmc.gov.my/skmmgovmy/media/General/pdf/ IUS-2020-Infographic.pdf.

Malaysian Dental Council. 2019. Annual Statistics 2019. http:// mdc.moh.gov.my/uploads/mdc statistic.pdf.

Naing, L., Winn, T. \& Rusli, B. 2006. Practical issues in calculating the sample size for prevalence studies. Arch. Orofac. Sci. 1: 9-14.

Nguyen, L.H., Drew, D.A., Graham, M.S., Joshi, A.D., Guo, C.G., Ma, W., Mehta, R.S., Warner, E.T., Sikavi, D.R. \& Lo, C.H. 2020. Risk of COVID-19 among front-line health-care workers and the general community: A prospective cohort study. The Lancet Public Health 5(9): e475-e483.

Oral Health Program, Ministry of Health Malaysia 2020. Garis Panduan Pengendalian Isu-Isu Berhubung Penularan Jangkitan Wabak COVID-19 di Perkhidmatan Kesihatan Pergigian Bil. 3/2020. http://ohd.moh.gov.my/images/pdf/ GP_COVID19_DENTAL_BIL3_2020.pdf 
Pantea Stoian, A., Pricop-Jeckstadt, M., Pana, A., Ileanu, B.V., Schitea, R., Geanta, M., Catrinoiu, D., Suceveanu, A.I., Serafinceanu, C., Pituru, S., Poiana, C., Timar, B., Nitipir, C., Parvu, S., Arsene, A., Mazilu, L., Toma, A., Hainarosie, R., Ceriello, A., Rizzo, M. \& Jinga, V. 2020. Death by SARSCoV 2: A Romanian COVID-19 multi-centre comorbidity study. Sci. Rep. 10(1): 21613.

Pfordten, D. \& Ahmad, R. 2020a. 'COVID-19: Total cases worldwide'. The Star. https://www.thestar.com.my/news/ nation/2020/01/26/the-rapid-global-spread-of-the-novelcoronavirus---total-cases-so-far.

Pfordten, D. \& Ahmad, R. 2020b. COVID-19: Cases up by 1, 371, bringing total to 84,846 (updated daily). The Star. https:// www.thestar.com.my/news/nation/2020/03/23/covid-19current-situation-in-malaysia-updated-daily.

Ren, Y., Feng, C., Rasubala, L., Malmstrom, H. \& Eliav, E. 2020. Risk for dental healthcare professionals during the COVID-19 global pandemic: An evidence-based assessment. J. Dent. 101: 103434.

Shah, A.U.M., Safri, S.N.A., Thevadas, R., Noordin, N.K., Rahman, A.A., Sekawi, Z., Ideris, A. \& Sultan, M.T.H. 2020. COVID-19 outbreak in Malaysia: Actions taken by the Malaysian government. Int. J. Infect. Dis. 97: 108-116.

Tysiac-Mista, M. \& Dziedzic, A. 2020. The attitudes and professional approaches of dental practitioners during the COVID-19 outbreak in Poland: A cross-sectional survey. Int. J. Environ. Res. Public Health 17(13): 4703.

WHO. 2020a. Timeline of WHO's Response to COVID-19. https://www.who.int/news/item/29-06-2020-covidtimeline.

WHO. 2020b. Coronovirus Disease (COVID-19). https://www. who.int/docs/default-source/coronaviruse/situationreports/20201005-weekly-epi-update-8.pdf.

WHO. 2020c. Considerations for the Provision of Essential Oral Health Services in the Context of COVID-19: Interim Guidance. https://apps.who.int/iris/handle/10665/333625. Accessed on 3 August 2020.
WHO. 2020d. COVID-19 Situation Overview in Malaysia (23rd July 2020). https://www.who.int/malaysia/internalpublications-detail/covid-19-in-malaysia-situationreport-09.

Zhou, W., Wang, A., Xia, F., Xiao, Y. \& Tang, S. 2020. Effects of media reporting on mitigating spread of COVID-19 in the early phase of the outbreak. Math. Biosci. Eng. 17(3): 2693-2707.

Shani Ann Mani* \& Sabri Musa

Department of Paediatric Dentistry and Orthodontics

Faculty of Dentistry

University of Malaya

50603 Kuala Lumpur, Federal Territory

Malaysia

Nor Azlida Mohd Nor

Department of Community Oral Health \& Clinical Prevention Faculty of Dentistry

University of Malaya

50603 Kuala Lumpur, Federal Territory

Malaysia

Jacob John

Department of Restorative Dentistry

Faculty of Dentistry

University of Malaya

50603 Kuala Lumpur, Federal Territory

Malaysia

*Corresponding author; email: shani@um.edu.my

Received: 29 January 2021

Accepted: 15 April 2021 